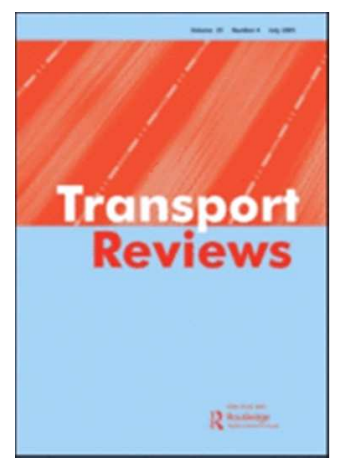

\title{
Distributive justice and equity in transportation
}

\begin{tabular}{|r|l|}
\hline Journal: & Transport Reviews: A Transnational Transdisciplinary Journal \\
\hline Manuscript ID & TTRV-2015-0077.R2 \\
\hline Manuscript Type: & Original Article \\
\hline Keywords: & $\begin{array}{l}\text { Accessibility, Equity, Justice, Distributive Justice, Social exclusion, } \\
\text { Transport Poverty, Ethics, Capability Approach, Rawls }\end{array}$ \\
\hline
\end{tabular}

\section{SCHOLARONE ${ }^{\text {M }}$}

Manuscripts 


\title{
Distributive justice and equity in transportation
}

\author{
Authors: \\ Rafael H M Pereira *+ \\ Tim Schwanen * \\ David Banister *
}

Abstract

Over the past decades, transport researchers and policymakers have devoted increasing attention to questions about justice and equity. Nonetheless, there is still little engagement with theories in political philosophy to frame what justice means in the context of transport policies. This paper reviews key theories of justice (utilitarianism, libertarianism, intuitionism, Rawls' egalitarianism, and Capability Approaches), and critically evaluates the insights they generate when applied to transport. Based on a dialogue between Rawlsian and Capability Approaches, we propose that distributive justice concerns over transport disadvantage and social exclusion should focus primarily on accessibility as a human capability. This means that, in policy evaluation, a detailed analysis of distributional effects of transport policies should consider minimum standards of accessibility to key destinations and the extent of which these policies respect individuals' rights and prioritize disadvantaged groups, reduce inequalities of opportunities and mitigate transport externalities. A full account of justice in transportation requires a more complete understanding of accessibility than traditional approaches have been able to deliver to date.

\footnotetext{
* Transport Studies Unit, School of Geography and the Environment, Oxford University

+ Institute for Applied Economic Research (Ipea), Brazil

author for contact: rafael.pereira@seh.ox.ac.uk
} 


\section{Introduction}

The number of studies concerned with justice and equity in transportation has dramatically increased in recent decades. This literature addresses multiple questions including: which neighborhoods of a city benefit from transport infrastructure projects and service provision (Currie, 2010; Foth et al., 2013); how policies impact the affordability of transport goods and services for different income classes (Levinson, 2010; Pucher, 1981), and which social groups are more exposed to transport-related externalities, such as pollution and traffic accidents (Feitelson, 2002; Forkenbrock \& Schweitzer, 1999). Despite the centrality of these and related questions to transport planning, there is little conceptual clarity about what justice means in the transport context. This lack of conceptual clarity makes it difficult to compare the findings from different studies and to obtain insights that could inform policy decisions.

The purpose of this paper is to engage with the political philosophy of justice and to explore some of its contributions and limitations in providing a distributive justice perspective on transport research and policy. We review key theories of justice (utilitarianism, libertarianism, intuitionism, Rawls' egalitarianism and Capability Approaches), and discuss some of their insights and limitations when applied to issues of transport disadvantage, social exclusion and accessibility. We focus on these issues because they are the most widely discussed issues in studies on equity in transportation (Geurs et al., 2009; Lucas, 2012). In this literature, concepts are also used to denote different things and sometimes without rigorous definitions. Moreover, there is often limited engagement with the philosophical literature on justice, even if a small but expanding number of publications explore how different ethical theories and principles can be used to incorporate equity concerns in transport planning and appraisal (Davoudi \& Brooks, 2014; Khisty, 1996; Lucas et al., 2015; Martens, 2012, 2016; Mullen et al., 2014; Van Wee \& Roeser, 2013). Such works tend to advocate pluralistic perspectives on justice, drawing on different moral principles that need to be balanced in each situation, and argue for a focus on accessibility when addressing questions over distributive justice and transport disadvantage.

The current paper differs from previous research by proposing a distributive justice perspective that stages a dialogue between theoretical works of John Rawls and 
Capability Approaches, two of the most prominent theories in political philosophy. It accommodates universalist concerns about inequality of opportunities and basic needs regarding transport and also considers context-specific issues regarding how people's transport choices are bounded by both personal and contextual factors. This perspective also holds that a full account of justice in transportation demands a more complete understanding of accessibility as a human capability.

There is no single overarching definition of justice. As an initial approximation and based on different theoretical traditions (Fraser, 1995; Kymlicka, 2002; Young, 1990), justice can be understood as a broad moral and political ideal that relates to: (1) how benefits and burdens are distributed in society (distributive justice); (2) the fairness of processes and procedures of decision and distribution (procedural justice); and (3) the rights and entitlements which should be recognized and enforced. Similarly, the concept of equity has been understood in various ways, including a demand for impartiality (Sen, 2009), proportionality between an individual's reward and cost/effort (Schweitzer \& Valenzuela, 2004), treatment of people according to their differences (Rawls, 1999), and the consideration of particular circumstances in ethical judgments (Barry, 1965). Even if the word equity is used to refer to particular elements of a broader idea of justice, the academic literature tends not to draw a clear distinction between the two concepts. We therefore use the terms equity and justice interchangeably. While equity always implies a moral judgment, equality does not have to imply a normative stance if the term is used in a descriptive sense to indicate full equality or sameness (Van Wee \& Geurs, 2011). Nevertheless, perfect equality is not a sufficient condition for achieving fairness (Rawls, 1999). Some authors recognize not all inequality is unfair and, in fact, fairness comes sometimes at the price of treating people differently according to their differences and even limiting some individual liberties (Dworkin, 1981; Rawls, 1999; Sen, 2009).

\section{An overview of theories of justice in political philosophy}


The political philosophy literature has long discussed the idea of justice, with liberal philosophers dedicating special attention to questions regarding the fair distribution of material and non-material goods in society. The liberal understanding of justice is characterized by two fundamental principles: respect for individuals' autonomy and moral equality, according to which all people deserve equal respect and consideration (Kymlicka, 2002). Yet, liberal thinkers have different conceptions of liberty and moral equality, offering different answers to three interrelated central questions about distributive justice that cannot be addressed in isolation from each other: (i) what - that is, which benefits and burdens - should be distributed?; (ii) on which moral principles should distribution patterns be based?; and (iii) what is the fairest distribution pattern? We discuss five justice theories that provide distinctive answers to these questions (see also Table 1 below) $)^{1}$.

\subsection{Utilitarianism}

Originally proposed by Jeremy Bentham and John Stuart Mill, utilitarianism is among the most influential theories of justice, not least because it provides the ethical foundation of cost-benefit analysis (Hausman \& McPherson, 2006). Utilitarianism is based on three key assumptions, which structure its understanding of justice. Firstly, utilitarianism is premised on the view that human well-being ('utility') is the only thing with intrinsic value and therefore is the core of justice concerns (Kymlicka, 2002). Secondly, utilitarians interpret the principle of equal respect as giving equal weight to everyone's welfare and interests, "regardless of the content of the preferences or the material situation of the person" (ibid.). Finally, utilitarianism holds a strictly consequentialist view: the moral judgment of an action or policy should be based exclusively on its consequences, particularly in how it maximizes well-being (ibid). Accordingly, the policy that best aggregates people's conflicting preferences becomes simply a matter of efficient administration, where the best alternative is the one which maximizes aggregate net welfare for the greatest number of people (ibid.).

\footnotetext{
${ }^{1}$ Questions of how distributive policy is decided and by whom have attracted much less attention in the political philosophy literature (Young, 1990). Similarly, this paper does not cover the concept "right to the city" (Fincher \& Iveson, 2012) nor feminist theories of justice because they go beyond the scope of distributive justice.
} 
Despite its attractive simplicity, the utilitarian approach is contested as a moral theory. Three criticisms are particularly important in the transportation context. Firstly, there is no particular concern with how well-being is distributed between individuals; this can be especially problematic when the promotion of aggregate welfare comes at the expense of the least well-off (Sen, 2009). Secondly, utilitarians overlook how some people's preferences may be illegitimate as they violate rights and reduce the liberties of others (Kymlicka, 2002). Finally, the combination of strict consequentialism and emphasis on maximizing aggregate well-being conflicts with the idea of respecting individuals' rights (ibid.). From an utilitarian perspective, for example, it is perfectly acceptable to override individual rights of minorities if this promotes a greater good for a greater number of people. Underlying this perspective is the Kaldor-Hicks compensation principle, according to which a project is worthwhile and equitable if its benefits are large enough so that winners could hypothetically compensate the losers, even if no compensation is provided (Hausman \& McPherson, 2006). Although all theories of justice take consequences into account in evaluating the rightness of actions (Kymlicka, 2002), the traditions discussed below take a deontological approach to ethics, i.e. they understand certain actions to be categorically wrong, even if they promote an increase in overall welfare (Sandel, 2009).

\subsection{Libertarianism}

The idea of self-ownership is at the heart of the libertarian conception of justice presented by Nozick (2003). It recognizes that all individuals equally share some fundamental rights (e.g., to one's own life and property) and the freedom to choose how to lead one's life according to one's values and goals, without interference by the state or others, provided the rights of others to do the same are respected (Hausman \& McPherson, 2006). Accordingly, libertarians claim free markets are inherently just and work as the primary instrument to promote justice, inasmuch as they result from voluntary choices by consenting adults, and are the best mechanism for efficiently maximizing social wealth (Kymlicka, 2002).. State interventions such as regulation, taxes and subsidies should be limited as they tend to distort market functioning (ibid.). 
Criticisms to libertarian conception of justice abound (Kymlicka, 2002; Sandel, 2009; Sen, 2009); suffice it to note that its understanding of individual freedom overlooks the fact that a person's preferences and achievements are never solely dependent on her individual choices, which cannot be fully separated from the natural and social contingencies of her context (ibid). When it comes to an individual's actions (e.g., travel behavior) with second-order effects on other members of the community (e.g., vehicle emissions, traffic accidents, congestion), libertarians believe self-regulated markets can provide adequate solutions to unfair or inefficient outcomes that emerge from collective action. However, free markets are not efficient or, arguably, fair in the presence of market failures (Hausman \& McPherson, 2006). Additionally, consent in market transactions is not a sufficient condition for justice, particularly when contracts involve large power imbalances, as is often the case in free markets (Sandel, 2009). In the end, while utilitarianism gives priority to aggregate well-being over individual rights, libertarianism gives priority to individuals' liberties, even if they come at the expense of human welfare (Kymlicka, 2002).

\subsection{Intuitionism}

Intuitionism is not a single theory of justice, but rather refers to the perspectives shared by authors for whom moral propositions are self-evident and basic moral knowledge is acquired through intuition (Rawls, 1999). Intuitionist authors such as Barry (1965) and Miller (1999) share the belief that moral problems in real life situations are so complex and diverse that only a pluralistic conception of justice can properly deal with them.

In contrast to utilitarianism and libertarianism, which put forward universal theories about justice, intuitionism argues for a more context-dependent and pluralistic approach. The decision of what is the right thing to do depends on the particularities of each moral dilemma, and may demand the consideration of different moral values, such as merit, basic needs, rights, formal equality, compensation, non-discrimination or procedural fairness (Barry, 1965). In transport planning processes, for example, procedural fairness demands all affected communities should be equally heard. When it comes to setting public transport fares, one could evoke the principle of compensation so people receive transport subsidies according to their financial constraints. 
This context-dependent nature of intuitionism, however, is also a main source of criticism. From (universalist) theoretical perspectives, intuitionism is unsatisfying since it proposes a series of ultimately arbitrary moral principles not specified by any consistent logical argument (Kymlicka, 2002; Rawls, 1999). From a practical viewpoint, intuitionism is of little help because it is unclear when each principle would be the right one to choose or how one should proceed to reconcile or prioritize competing moral principles (ibid.).

\subsection{Rawls' egalitarianism}

Rawls' theory of justice is essentially concerned with the role played by institutions in promoting justice (Rawls, 1999, 2001). His theory is comprised of two overarching principles, ordered by priority. The first principle has absolute priority and applies particularly to basic rights and liberties. ${ }^{2}$ It holds that the rules defining individuals' basic rights and liberties ought to apply equally to everyone and that individuals should have as much freedom as possible as long as this does not infringe the freedom of others (ibid.). The second principle applies to the distribution of primary goods, which are various social conditions and all-purpose means that are necessary to enable citizens to pursuit their life plans (whatever they may be); they include in broad categories income and wealth, opportunities, powers and prerogatives of authority and the social bases of self-respect. This second principle contends that social and economic inequalities can only be considered fair if they simultaneously (a) derive from a situation of fair equality of opportunity, and (b) work to the benefit of the least advantaged members of society (ibid.).

The idea of equality of opportunity stresses the importance of individual freedom of choice. It implies that in a society with genuine equality of opportunity inequalities are legitimate, provided they result from people's choices and efforts; inequalities are unfair if they result from morally arbitrary circumstances such as being born in a poor family or ethnic group (Kymlicka, 2002). Rawls (1999) nonetheless acknowledges that some level of inequality is inescapable and that it is not possible to

\footnotetext{
${ }^{2}$ These include freedom of thought and of association, political liberties, the rights and liberties covered by the rule of law and the physical and psychological liberty and integrity of the person (Rawls, 2001).
} 
achieve genuine equality of opportunity because individuals' innate or trained abilities, freedom of choice and even effort cannot be completely separated from their social conditions. Since no one can claim credit for their innate capacities, nor for the initial position in society in which they were born, it is unfair for individuals to be penalized or privileged by such arbitrary circumstances. This leads Rawls to argue in the second part of his second principle - known as 'difference principle; - that inequalities can only be considered fair if they work to the benefit of the least well-off, thereby mitigating inequalities of opportunities and the morally arbitrary effects of social and natural lotteries (ibid). In practical terms, the difference principle points to a distributive rule based on the maximin criterion, suggesting one should choose the policy alternative that maximizes the minimum level of primary goods of the people in the worst-off position (ibid.). Furthermore, Rawls' theory of justice does not require inequality levels to be restricted to a maximum gap, except in those cases where the increase of primary goods at the top of the distribution would begin to have negative effects on those at the bottom. In such circumstances the notions of fraternity and mutual benefit embedded in the difference principle give moral justification for institutions to limit the upper part of the distribution (Rawls, 1999, 2001).

Two criticisms of the difference principle should be noted. Although Rawls acknowledges the difference between inequalities that emerge from personal choices and those that emerge from morally arbitrary circumstances, the difference principle does not make such a distinction (Kymlicka, 2002). Consequently, this principle mitigates not only the unfair effects of morally arbitrary circumstances but also the legitimate effects of personal choices and effort (ibid.). This issue extends beyond Rawls' difference principle and is a crucial problem for any policy design seeking to distinguish between choice and circumstances in real life settings (Dworkin, 1981).

\subsection{Capability Approaches}

Another important criticism of Rawls' theory comes from Amartya Sen who endorses Rawls' overall scheme but proposes that the focus of the difference principle should shift from primary goods to human capabilities (Sen, 1979, 2005, 2009). Capabilities are sets of freedoms and opportunities available for individuals to choose and to act, 
resulting from "[...] a combination of personal abilities and the political, social and economic environment" (Nussbaum, 2011). Although the Capability Approach (CA) is not intended to be a full theory of justice, human capabilities are at the heart of justice concerns, which essentially deal with the opportunities and substantive freedoms that enable individuals to achieve things they have reason to value (Sen, 2009).

For Sen (ibid), the focus on the distribution of resources or primary goods is incapable of recognizing the diversity of human needs and preferences. This is because goods, services or income are not ends in themselves, but merely means to valued ends. Most of the time, a car or a bicycle is not something we value for its own sake, but only to the extent it helps us achieve our aspirations in symbolic, aesthetic or practical terms. Additionally, the capacity of each person to convert a particular resource into pursued ends depends heavily on her social context, preferences, skills, etc.. Hence, what matters from the moral point of view is not so much the distribution of resources, but people's capacities to convert such resources into a good life made up of 'functionings' (practices) according to their own preferences.

The CA recognizes the influence that a person's environment has in enhancing or restricting the set of opportunities that are available for her to choose (Nussbaum, 2011; Robeyns, 2005). It takes into account not only the diversity of individuals' characteristics (e.g. preferences, values, needs, abilities), but also the societal structures and constraints affecting individuals' capacities to convert resources and opportunities into functionings. This interaction between internal capabilities and external environment is what Nussbaum (2011) refers to as 'combined capabilities'. Accordingly, assessments of justice and social life conditions ought to differentiate the possibilities of what a person is able to do (her capability set) from what the person ends up doing - her functionings (Sen, 2009).

Sen acknowledges the importance of reducing capability inequalities to promote equality of opportunities (Sen, 1999, 2009) . However, the CA is primarily concerned with promoting basic capability equality by guaranteeing minimum levels of basic capabilities (Sen, 1979). These basic capabilities refer to the freedom to do things that are essential for survival and later development, and include, for example, being able to move around, participate in the social life of the community, and meet one's nutritional requirements (Nussbaum, 2011; Robeyns, 2005). In this sense, the CA share both 
egalitarian and sufficientarian concerns discussed by Van Wee and Geurs (2011) and Lucas et al (2015). For Sen, the definition of a list of basic capabilities and minimum thresholds must be culture-dependent. It ought to take into account each society's particular values and material conditions, and may even change across time as societies develop and reassess their political positions (Sen, 2005, 2009). Others, following Nussbaum, argue that even if the definition of acceptable minimum thresholds is context-dependent, a more or less universal list of central capabilities that any state would need to guarantee to all citizens can be identified. These include, among others, the capabilities of being able to participate effectively in political decisions that affect one's life, to move freely from place to place and having good health (Nussbaum, 2011).

Table 1: Summary of key theories of justice

\begin{tabular}{|c|c|c|c|c|}
\hline $\begin{array}{l}\text { Theories of } \\
\text { justice }\end{array}$ & Distribution of what? & $\begin{array}{l}\text { Guiding principle of } \\
\text { distribution }\end{array}$ & $\begin{array}{l}\text { The fairest distribution } \\
\text { pattern }\end{array}$ & $\begin{array}{c}\text { Key } \\
\text { Authors }\end{array}$ \\
\hline Utilitarianism & $\begin{array}{l}\text { Welfare, well-being, } \\
\text { utility }\end{array}$ & $\begin{array}{l}\text { The greatest good for the } \\
\text { greatest number }\end{array}$ & $\begin{array}{l}\text { Whatever distribution that } \\
\text { maximizes aggregate welfare }\end{array}$ & $\begin{array}{l}\text { Jeremy } \\
\text { Bentham } \\
\text { and John } \\
\text { Stuart Mill }\end{array}$ \\
\hline Libertarianism & Basic rights and liberties & Self-ownership & Absolute equality & $\begin{array}{l}\text { Robert } \\
\text { Nozick }\end{array}$ \\
\hline Intuitionism & $\begin{array}{l}\text { Different 'whats', e.g. } \\
\text { resources (food, money } \\
\text { etc.), services (health, } \\
\text { education etc.) }\end{array}$ & $\begin{array}{l}\text { Particular distributive } \\
\text { problems demand different } \\
\text { principles be applied to } \\
\text { particular cases (e.g. rights, } \\
\text { deserts, needs, expectations, } \\
\text { procedural justice, etc.) }\end{array}$ & No clear distribution pattern & $\begin{array}{l}\text { Brian Barry } \\
\text { and David } \\
\text { Miller }\end{array}$ \\
\hline $\begin{array}{l}\text { Rawls' } \\
\text { Egalitarianism }\end{array}$ & $\begin{array}{l}\text { Basic Liberties } \\
\text { Opportunities } \\
\text { Primary goods (rights } \\
\text { and prerogatives of } \\
\text { authority, income and } \\
\text { wealth) }\end{array}$ & $\begin{array}{l}\text { First principle (deontological } \\
\text { justification) } \\
\text { Fair equality of opportunity as } \\
\text { pure procedural justice }\end{array}$ & $\begin{array}{l}\text { Equal distribution } \\
\text { Equal distribution } \\
\text { Maximin criterion: The } \\
\text { distribution that maximizes, } \\
\text { subject to constraints, the } \\
\text { prospects of the least } \\
\text { advantaged groups }\end{array}$ & John Rawls \\
\hline $\begin{array}{l}\text { Capabilities } \\
\text { approach }\end{array}$ & $\begin{array}{l}\text { Opportunities } \\
\text { Central/basic } \\
\text { capabilities }\end{array}$ & $\begin{array}{l}\text { Human dignity and equal } \\
\text { respect }\end{array}$ & $\begin{array}{l}\text { Equal distribution } \\
\text { All should get above } \\
\text { a minimum basic level }\end{array}$ & $\begin{array}{l}\text { Amartya } \\
\text { Sen and } \\
\text { Martha } \\
\text { Nussbaum }\end{array}$ \\
\hline
\end{tabular}




\section{Transport disadvantage, social exclusion and equity in transportation}

At least since the $1960 \mathrm{~s}$, transportation scholars have investigated how transport disadvantages can lead to social exclusion and compromise the well-being of individuals (e.g. Kain, 1968; Wachs \& Kumagai, 1973). This literature is also fundamentally concerned with issues of distributive justice, and this section reviews how this literature addresses the three questions raised in the introduction section.

Regarding the first question (distribution of what), the literature emphasizes three types of transport-related inequalities that are interconnected and have key influence on people's well-being: inequalities of transport-related resources, observed daily travel behavior and transport accessibility levels. Many studies focus on the unequal distribution of transport-related resources, such as car ownership and proximity to transport services and infrastructure (e.g. Murray \& Davis, 2001; Ong, 2002; Thomopoulos et al., 2009). One insight from the Capabilities Approaches is that this focus on resources can be misleading. Because people's needs, preferences and abilities/skills are so heterogeneous, this focus provides only a partial account of individuals' capacity to use such resources to move around the city and to reach desired activities. For example, proximity to transit services is of little use if they are not affordable, if the transport system is not adequately adapted to disabled people, or if that system does not connect the places between which individuals need to travel. Even bicycle use for daily transportation demands, apart from an appropriate built environment and safe cycling infrastructure, some level of bodily fitness and health that is not equally available to all individuals.

Meanwhile, other researchers focus on inequalities in daily travel behavior, including differences in trip frequency, traveled distances and travel time - the idea being that such travel patterns reflect different levels of well-being and participation in society (Bills et al., 2012; Karlström \& Franklin, 2009; Vasconcellos, 2005). As a general rule, the academic literature assumes transport decisions to be primarily a matter of individual choice and personal responsibility (Mullen, 2012). However, it is not always possible to tease out how much inequality in travel behavior arises from 
individuals' tastes and preferences (voluntary choice) and from contextual constraints outside individual control. Longer commutes, for example, can arise due to affordable housing only being available in more distant locations, but also reflect preferences for suburban living.. While this differentiation is difficult to deduce from data on observed travel behavior, such information is crucial to determine, for instance, whether certain behaviors are entitled to public subsidy.

Furthermore, the focus on observed travel behavior overlooks the unfulfilled needs of less mobile groups, ignoring the suppressed demand for those trips that would have been taken were it not for constraints imposed by the transport system or by other economic and social reasons (Nordbakke \& Schwanen, 2015). Similarly, this type of analysis does not capture what range of places the transport system actually makes accessible to the population. From the perspective of expanding people's potential mobility and freedom of choice, it is crucial to differentiate the places people actually go to from the range of places they are able to reach. From a social justice and environmental perspective, there are considerable differences between policies that increase people's actual mobility and those that enhance people's capability to access desired destinations if they so choose (Banister, 1994).

A more promising approach than considering travel behavior is to focus on inequalities in accessibility levels. Accessibility is conceptualized and measured in many different ways, and some conceptualizations and methods are more compatible with certain ethical perspectives than others (Martens \& Golub, 2012; Neutens et al., 2010; Van Wee \& Geurs, 2011). From a justice perspective, accessibility can usefully be conceptualized as the ease with which persons can reach places and opportunities from a given location and be understood as the outcome of the interplay of characteristics of individuals, the transport system and land use (Kwan, 1998; Neutens et al., 2010). A substantial literature on inequalities in transport accessibility (e.g. Church et al., 2000; Delmelle \& Casas, 2012; Welch, 2013) considers accessibility as a necessary, though not sufficient, condition for the expansion of people's freedom of choice and promotion of equality of opportunities in terms of employment, healthcare, education services, etc. The focus on accessibility is also justified since a primary purpose of transport policy is to improve access to places, activities and opportunities people have reason to value (Martens et al., 2012; Van Wee \& Geurs, 2011). 
The second question regarding distributive justice concerns the moral principles that should guide and justify redistribution. This is perhaps the most overlooked question in the transport literature: most existing studies neither justify why observed inequalities in transport-related benefits and burdens should be considered unfair, nor offer any moral reasoning to guide us towards a fairer distribution. There are some exceptions which apply a broad conception of political and social equality to walking and cycling policies (Mullen et al., 2014) and which propose a non-market-based distribution of transport accessibility (Martens, 2012). Others studies examine the link between accessibility and general principles of equality and basic needs (Lucas et al., 2015) and raise a variety of ethical principles to guide transport policies (e.g. Litman, 2002; Trinder et al., 1991) but without committing to any specific theory of justice (see section 4).

The third question about how benefits and burdens can be distributed in the fairest way has been addressed from two different perspectives. The first - egalitarian approach frames this as a question of relative distribution and focuses on inequality between social groups or geographical areas, asking why certain groups/areas have higher or lower accessibility levels or transport goods/services than others (Benenson et al., 2011; Kawabata \& Shen, 2007; Meijers et al., 2012). The second - sufficientarian approach is framed in terms of transport poverty and basic needs, considering why some groups/areas simply do not have/offer enough access to those goods and services (e.g. Delbosc \& Currie, 2011; Jaramillo et al., 2012). The first approach implicitly assumes there is an ideal or acceptable level of inequality considered to be fair. The idea underlying the second approach is that there are minimum levels of transport goods, services and accessibility to essential activities that should be available to everybody. Elaborations of both approaches to date can be criticized. Studies in the first category tend not to make clear statements about acceptable levels of inequality, what an ideal distribution pattern looks like, or how far transport policies should go in reducing inequalities. Research in the second group suffers from the conundrum that no minimum thresholds can be established without paternalistic assumptions that overlook the diversity of people's preferences and needs (Cass et al., 2005; Preston \& Rajé, 2007).

In summary, studies on distributive justice in relation to transportation are primarily descriptive, containing little or no explicit theoretical reflection on justice. 
The literature gives diverse answers to key questions regarding distributive justice, and rarely addresses such questions in a systematic way (Martens, 2011), often leaving some of these questions unanswered. Transport accessibility, rather than resources or travel behavior, stands out as the most promising focal variable of distributive justice. In whatever way accessibility is conceptualized and measured, the ethical perspective should be made explicit because different theories of justice give different answers to how policies should address inequalities in accessibility. In what follows, we present our interpretation of what insights the theories analyzed in section 2 could bring to policies focused on accessibility.

\section{Insights from political philosophy for transport policy and accessibility}

\subsection{Utilitarians}

Utilitarians are not interested in accessibility in itself, but only in the instrumental value of actual trips for the promotion of those activities from which people derive utility. From this perspective, urban and transport policies should be designed to facilitate trips to those activities that maximize aggregate utility. However, since the utility derived from an activity is commonly measured by people's willingness to pay, and because benefits derived from transport projects have traditionally been evaluated in terms of the monetary value of travel time savings, an unintended consequence of utilitarian evaluations is that they implicitly prioritize accessibility gains to more profitable activities and people with higher incomes and hence higher values of time. This and other criticisms to utilitarian reasoning in traditional transport planning have been raised by critics of cost-benefit analysis (e.g. Martens, 2011; Van Wee, 2012; Van Wee \& Roeser, 2013).

Because the well-being of everyone is seen as equally important, a utilitarian approach focuses on aggregate measures of transport performance, paying no particular attention to howaccessibility is distributed among individual members of society (ibid). In such evaluations it would not matter if, for example, the promotion of transport 
accessibility for higher income classes and car drivers came at the expense of reducing the accessibility of lower classes and public transport users. Although this issue can be addressed partially by project evaluations using utility-based weights to capture variations of benefits/costs between affected groups/individuals (Lucas et al., 2015), the utilitarian approach still faces serious shortcomings regarding the measurement and interpersonal comparison of the utility people derive from transport improvements (Rietveld et al., 2007). Additionally, the strict consequentialism espoused by utilitarians means that situations in which transport policies violate the rights of minorities are not seen as a moral problem, as long as such policies bring about net benefits to a larger number of people. From a utilitarian perspective, the eviction of, say, hundreds of families in order to expand a road would be perfectly acceptable, even if those families were not compensated in an appropriate manner.

\subsection{Libertarianism}

The libertarian approach would also have no particular concern about how accessibility is distributed among members of society, but for a different reason. According to libertarians, the fairest distribution of transport accessibility would be whatever distribution resulted from free market transactions between consenting adults. According to this view, the free market is the best instrument to expand people's choices about how to better satisfy their transport needs, and to make individuals fully responsible for their own choices. The state should play no role in terms of taxes and subsidies, and state regulation should be limited to the minimum necessary to establish clear property rights and due compensation when contracts are broken (Klein et al., 2003; Winston, 2000). This view resonates with the emergence of unregulated ondemand ridesharing companies such as Uber and Lyft, whose services could be considered somewhat closer to a pure market solution to urban transportation, despite being heavily dependent on government-provided road infrastructure.

However, this idea that free market and its price system can work as the sole device to promote just and efficient transport solutions disregards the possibility of conflict between markets and distributive fairness. It overlooks how efficiency might be 
in conflict with equity and how these two goals are often jeopardized by market failures that typically occur in urban transportation (Estache \& Gómez-Lobo, 2005; Glaister et al., 1990; Santos et al., 2010). Because mass transportation services work under a regime of natural monopoly, unregulated competition of transport companies is often inefficient and sub-optimal. Under such conditions, private companies have no economic incentives to consider the special needs of minority groups such as people with disabilities, to provide public goods such as urban roads, and to provide transport services to distant and impoverished neighborhoods where services are less profitable. The emphasis on individual transport decisions coupled with unregulated use of public goods such as urban roads can lead to overuse of road space, aggravating negative externalities, including congestion, air pollution and traffic accidents (ibid.).

\subsection{Intuitionism}

An intuitionist approach to transport policies is context sensitive, and the allocation of transport investments and services to improve people's accessibility may be guided by different moral justifications (e.g., basic needs, formal equality, horizontal and vertical equity) across individual cases (Hay, 1993; Hay \& Trinder, 1991; Khisty, 1996; Litman, 2002). For example, the need to access essential activities (e.g., education and health services) could be used to justify allocation of subsidies and services for certain groups (e.g., students, low-income classes, deprived neighborhoods) to guarantee they have minimum levels of accessibility to those activities. As often happens in the policy context, however, allocation dilemmas usually involve a plurality of competing principles of justice leading to different policy alternatives and it is not straightforward to decide which principle and distribution rules should prevail on specific occasions. For example, while formal equality would support transit services being equally distributed in all areas of a city and all passengers paying equal transport fares, compensation would justify prioritizing services in poorer neighborhoods and would allow for the provision of fare concessions to vulnerable groups such as the elderly or disabled. There is, moreover, little consistency across transport studies using this intuitionist approach (ibid.). Different lists of intuitions deemed relevant for project 
evaluation have been put forward, often without consistent definitions of what each intuition means.

The risk of an intuitionist approach lies in its evaluation of distributive conflicts becoming too context specific. It provides only limited guidance to policy decisions inasmuch as it does not offer any consistent moral scheme to balance various competing claims of justice. Under such approach, policy decisions may well be taken on an adhoc basis or following opportunistic claims that are electorally appealing at specific moments in time. Such decisions may also lead to incoherent and conflicting policies, with benefits of one policy potentially increasing the undesired effects of other policies.

\subsection{Rawlsian egalitarianism}

From a Rawlsian perspective (or rather, our interpretation of it), any transport project should be guided by respect for individuals' basic rights; no policy would be acceptable if it violated such rights, even if it improved people's accessibility. For example, even though Rawls $(1999,2001)$ acknowledges freedom of movement as a crucial liberty, arguing people should be free to move from place to place, this liberty should be exercised within the limit of not harming the basic rights including that of physical integrity of others. This position offers an important moral argument in favor of policies that discourage individual motorized transport in congested areas, because such transport disproportionately generates negative externalities that harm other people's health conditions through road congestion, air pollution and traffic accidents (Viegas, 2001).

In a more recent reassessment of his original theory, Rawls (2001, p.172) has broadened his understanding of primary goods to include personal goods and services provided by the state: "primary goods of income and wealth are not to be identified only with personal income and private wealth. [...] As citizens we are also the beneficiaries of the government's providing various personal goods and services to which we are entitled, as in the case of health care, or of its providing public goods (in the economist's sense), as in the case of measures ensuring public health (clean air and unpolluted water, and the like). All of these items can (if necessary) be included in the index of primary 
goods". This broadening is consistent with his idea that government services and public goods should be guided by the difference principle (Rawls, 1999, p.175, 246-267). Along with other authors (Khisty, 1996; Van Wee \& Geurs, 2011; Van Wee \& Roeser, 2013), we believe transport accessibility as well as governmental investments and services aimed at improving people's accessibility can be understood as primary goods to which the difference principle is applicable. This does not mean everybody should experience the same level of transport accessibility. In fact, from our interpretation of Rawls' theory, justice is not about whether some people enjoy greater accessibility than others but about how institutions and policies deal with such inequalities in order to minimize inequality of opportunities (Rawls, 1999, p.87). This interpretation may seem compatible with transport policies that aim to advance the common good by improving overall or average levels of accessibility. However, the application of Rawls' difference principle to transport entails that interventions such as infrastructure investments, subsidies and service provision can only be considered fair if they improve accessibility levels of the least advantaged groups. This is the case with policies that focus on improving accessibility of low-income classes living in deprived areas or policies that prioritize those transport modes most commonly used by low-income people (Van Wee $\&$ Geurs, 2011). While in dense urban areas this can be done through policies that prioritize public transport, walking and cycling over private cars (e.g., exclusive bus lanes, congestion charging schemes, cycle paths), policies that facilitate car use for lowincome people would likely be more appropriate in low-density and rural areas. Moreover, the difference principle would also provide ethical support for policies to limit the highest levels of car accessibility in circumstances where further increases in car use and concomitant negative externalities undermine the accessibility of public transport users and impose health burdens on vulnerable groups.

Rawls (1999, sections 43, 44; 2001, sections 38, 39) argues that at a certain point justice would also demand setting a minimum level of primary goods. In practice, governments should guarantee minimum levels of primary goods for all individuals so that at least the basic needs essential to a decent life - the definition of which differs across societies - are met; the allocation of primary goods above minimum thresholds can be allocated via regulated markets. Thus, Rawls's concept of appropriate social minimum goes beyond basic individuals' physiological needs and is dependent on a given society's wealth and public political culture, among other factors (ibid.). A similar 
idea has been proposed on the setting of minimum transport access to basic destinations such as food stores, schools and medical services (Delbosc \& Currie, 2011; Van Wee \& Geurs, 2011), although the definition of minimum accessibility thresholds still presents great challenges (see next section).

\subsection{Capability Approaches}

To date, various authors have argued that mobility in the sense of being able to move should be considered as a basic capability because of its central role in enabling people to satisfy basic needs (e.g. Beyazit, 2011; Kronlid, 2008; Robeyns, 2003; Sen, 2005; Tyler, 2006; Van Wee, 2012). While usefully highlighting mobility's instrumental importance to the development of other human capabilities, the idea of mobility as capability should be expanded into an understanding of accessibility as a combined capability.

According to our interpretation of the Capability Approaches, urban and transport policies should not only aim at increasing overall accessibility levels in society, so that individuals become better able to develop other capabilities and conduct the activities they have reason to value. Policies should also, and primarily, guarantee individuals a minimum level of access to those key activities that are essential for meeting basic needs, such as food stores, education, health services and employment opportunities. However, this does not imply that, as a necessary condition of justice, everybody must enjoy exactly the same transport conditions. This belief would amount to resource fetishism (Nussbaum, 2011) and overlook how people's ability to convert transport resources into capability and quality of life is affected by contingencies such as personal characteristics, physical environment and cultural norms (Ryan et al., 2015).

The application of Capability Approach to transport policy raises at least two challenges. The first is that understanding accessibility in capability terms couples accessibility needs with the idea of social rights insofar as some minimum level of accessibility is necessary for the satisfaction of individuals' basic needs and a necessary, though not sufficient, condition for people to exercise basic rights such as going to school, receiving health care and voting in elections. While this might go as far as raising a discussion on accessibility rights (Farrington, 2007), it certainly requires the 
identification of minimum acceptable thresholds of accessibility to key activities and demands government initiatives to guarantee the accessibility needs of people who fall below those thresholds. The identification of such minimum thresholds remains an unresolved challenge in the academic literature (Farrington \& Farrington, 2005; Hananel \& Berechman, 2016; Smith et al., 2012). It is nonetheless evident that their identification is dependent on a given society's history and values, and would require a political decision reached through a legitimate political and democratic process.

A second challenge is that understanding accessibility as a combined capability requires one to address accessibility as a result from a combination of personal abilities and the social, economic, and built environment, which is a more complex and multidimensional concept of accessibility than often used in transport studies (Tyler, 2006). For policy reasons, it is important to frame accessibility as a combined capability in respect of two analytically separable but interconnected accessibility components:

a) One component is the person's capability to access and use mobility technologies and transport systems/vehicles, which depends on the interplay of personal and external factors. Relevant personal factors may include, for example, physical and mental fitness, the motor and cognitive skills to understand and interact with the transport system, accumulated experience, and sufficient financial resources. Meanwhile, the external factors may refer to the social environment (e.g., whether a person is able to use the transport system without being harassed or discriminated), as well as to a transport system's physical design, provisions for disabled individuals, price levels, quality and availability of travel information, and so forth.

b) The other component of accessibility refers to how the interactions between the transport system and land use patterns enhance people's capabilities: given that a person is able to use a transport system/vehicle, does that system/vehicle actually improve her capacity to access desired places and opportunities? Even if a person is able to access and use a transport system, she may not necessarily be able to reach the destinations she wants to access. This is because accessibility as a combined capability also depends on timebudget restrictions of individuals and additional external factors related to 
land use patterns, how the transport network is distributed and connected across the city vis-à-vis the distribution of desired opportunities and activities, in addition to the transport system performance, including service frequency, reliability, speed, etc. This capability can also be extended beyond the spatial domain through information/communications technologies that allow people to access opportunities without having to move physically (Banister \& Hickman, 2006; Kenyon et al., 2002) ${ }^{3}$.

The understanding of accessibility as capability is not easily compatible with place-based conceptualizations that understand accessibility exclusively as an attribute of locations. Because the CA is fundamentally concerned about individual freedom of choice and human agency, this approach requires that accessibility be understood as an attribute of individuals in their interaction with their environment, taking into account how personal characteristics (such as gender, age, social class, disabilities, time budget) shape interpersonal differences in accessibility levels.

Even if one focuses on person-based accessibility, there is still a substantial variety of metrics which can be used to measure accessibility (e.g., utility-based and space-time measures). The choice of metric is significant and strongly shapes which conclusions can be drawn from accessibility analysis (Kwan, 1998; Neutens et al., 2010). Further research is needed to discuss which accessibility measures are conceptually consistent with different ethical frameworks (Martens \& Golub, 2012), and to discuss the challenges of building more comprehensive accessibility measures that go beyond the limits imposed by data conventionally used in transport surveys.

\section{Conclusion}

\footnotetext{
${ }^{3}$ This integral notion of accessibility is encompassed and further developed by the concept of motility (Flamm \& Kaufmann, 2006; Kaufmann et al., 2004). Motility incorporates how personal, social and environmental factors interact to form the processes that shape the relation between an individual's spatial and social mobility. The complex relation between the concepts of motility, accessibility and capability deserves more attention in future research on equity in transportation. We should note, though, these concepts generally overlook issues of externality from societal perspective.
} 
Given the strengths and limitations of the theories reviewed in previous sections, the overarching conclusion of this paper is that future studies addressing distributive issues in transportation equity would benefit from an ethical perspective that builds a dialogue between Rawls' egalitarianism and the Capability Approaches, which we only briefly sketch here ${ }^{4}$. When it comes to the question "distribution of what" under this perspective, accessibility is understood as a combined capability and should be the primary focus of transport researchers and policy makers addressing questions over distributive justice and transport disadvantage. This focus emphasizes the social and economic opportunities available for individuals to access if they so choose. This perspective thus stresses the link between accessibility and the ideas of agency and freedom of choice, while demanding a more nuanced and multidimensional understanding of accessibility that acknowledges the diversity of people's needs and constraints when they make their transport decisions.

With respect to the second question, the concern with accessibility is morally justified for different reasons. First, some minimum level of accessibility to key destinations is a basic capability that is necessary for people to satisfy their basic needs. Moreover, the concept of accessibility draws out the spatial dimension in moral concerns over equality of opportunities, which is a central concern of distributive justice but has thus far only been treated as a non-spatial idea by political philosophers. In this sense, accessibility works as a necessary, though not sufficient, condition for promoting equality of opportunity. It also has instrumental importance for the development of further capabilities and freedom of choice that allow people to flourish and pursue the life they have reason to value.

With regard to the question of what a fair distribution of accessibility should look like, this perspective contends, firstly, that individuals' basic rights and liberties should never be violated or sacrificed on the grounds of improving accessibility levels of others. Secondly, a transport policy is fair if it distributes transport investments and services in ways that reduces inequality of opportunity. While aiming to enhance overall levels of accessibility, policies should prioritize vulnerable groups and thereby mitigate morally arbitrary disadvantages that systematically reduce their accessibility levels,

\footnotetext{
${ }^{4}$ For a discussion on the integration of Rawls' theory and the capability approach applied to planning theory more broadly, see Fainstein (2010) and Basta (2015).
} 
such as being elderly, disabled or born in an ethnic minority or poor family (Lucas, 2012; Páez et al., 2010). Finally, this proposed framework gives support to the ideas of setting minimum standards of accessibility to key destinations which should be guaranteed by the government through social or transport policies if necessary, and limiting the highest levels of accessibility of social groups and transport modes only in those circumstances when a marginal improvement of accessibility at the upper levels would harm those groups at the bottom (see pages 18-19).

Some of the practical implications of this perspective can be illustrated with issues that commonly arise in cities with investments in public transport (e.g., metro and bus rapid transit developments) and cycling/walking. These types of investments can be good ways to prioritize transport modes which are more widely used by low-income classes. To be considered fair, however, these investments should not override the social rights of families threatened with eviction due to the infrastructure projects. The distributional effects of such investments should be evaluated in terms of the extent to which they reduce inequalities in transport accessibility, particularly by improving accessibility levels of low-income public transport-dependent groups to key destinations such as employment opportunities, healthcare and education services. According to this approach, the design of those transport projects (including design of vehicles, stations, cycle paths, etc.) must be inclusive towards social groups such as the elderly and disabled in order to minimize the impact that non-chosen disadvantages have on people's capacity to access activities. Moreover, this perspective also calls for complementary policies that discourage car use (e.g., congestion/parking charge, fuel tax) in highly congested and polluted areas to mitigate the negative externalities imposed by drivers on everyone else, particularly on vulnerable populations ${ }^{5}$.

One important advantage of this ethical perspective in addressing distributive justice is its ability to strike a balance between a universalist approach to justice and context-sensitivity. It offers a universalist perspective by providing a strong protection of individuals' rights and liberties. It also accommodates universalist concerns with the protection of basic capabilities that are necessary for individuals to satisfy their basic needs, for the promotion of equality of opportunities, and for ensuring a pluralistic

\footnotetext{
${ }^{5}$ To both Rawls and the capabilities approach, people's health/physical integrity should be protected inasmuch as it is understood either as an individual basic right or as a basic capability.
} 
society where individuals can lead the lives they value while respecting the rights of others. At the same time, this ethical perspective is contextualist by acknowledging that the identification of disadvantaged groups and appropriate policies to improve their accessibility are context-specific and that acceptable minimum thresholds of accessibility ought to be defined by each society according to its particular values and material conditions following due political process. Moreover, it acknowledges that evaluations of transport inequalities should hold people responsible for their choices but also recognizes how such choices are often constrained by people's needs, and by their social and built environments.

We believe this provisional and tentative dialogue between Rawls' theory and the Capability Approaches addresses both sufficientarian and egalitarian concerns about the economic, social and health prospects of disadvantaged groups. It is also flexible enough to apply to different dimensions of transport exclusion and inequalities related to gender, race/ethnicity, disability, segregated and impoverished neighborhoods, etc. We hope it will bring valuable insights to other aspects of equity related to transportation pricing and finance (Pucher, 1982; Santos \& Rojey, 2004), civil rights and spatial discrimination (Karner \& Niemeier, 2013; Sanchez et al., 2003) and environmental justice (Chakraborty, 2006; Schweitzer \& Valenzuela, 2004).

The ideas proposed here go in line with a broader concept of "just city" and how it seeks to build a dialogue between Rawls and Capabilities (Fainstein, 2010). For future studies, further exploration of synergies and divergences between Rawls' theory and the Capability Approaches is needed. A crucial challenge for this framework would be to prove its value in the evaluation of case studies of transport projects and policies in different spatial settings and at local and regional scales. Ideally, this would require more comprehensive accessibility measures that are consistent with the Capability Approach and go beyond conventional transport surveys to capture other factors that shape interpersonal differences in individuals' accessibility, including people's cognitive and embodied competencies, cultural norms, time constraints or whether the social environment is free from any kind of harassment and discrimination. While timegeographers have advanced many of these issues (Kwan, 1998; H. J. Miller, 2006), further research is required to discuss how the concept of motility can offer further insights into transportation equity and social exclusion (Kellerman, 2012). 
A distributive justice approach does not, however, exhaust all relevant concerns about equity in transportation. As Rawls and Sen themselves recognize, there is more to justice than fair distributions, which cannot be judged in isolation from the process of which they are an outcome (Rawls, 1999; Sen, 1999, 2005, 2009). This requires recognizing both the role of participatory planning as a crucial part of transport justice (Booth \& Richardson, 2001; Hodgson \& Turner, 2003), and that current policies and rights one might take for granted today are themselves result of historical processes and political disputes marked by power imbalances between social groups (Fincher \& Iveson, 2012). This is important because the way in which society understands the nature and role of transport accessibility will ultimately shape what a fair transport policy is. The conclusion that justice entails more than questions of distribution calls for a deeper engagement with critical philosophy and social science, which would help situate distributive justice in the broader context of participatory planning, democratic citizenship, the right to the city and spatial justice (Fainstein, 2010; Soja, 2010; Young, 1990).

Transportation equity studies unavoidably deal with normative discussions about what is to fair. To grapple this political challenge, a theoretically grounded understanding of distributive justice allows us to go beyond descriptive studies of transport inequalities and to advance justice in transport policies.

\section{References}

Banister, D. (1994). Equity and acceptability questions in internalising the social costs of transport, Internalising the social costs of transport. In OECD \& ECMT (Eds.), Internalising the Social Costs of Transport (pp. 153-175). Paris: OECD.

Banister, D., \& Hickman, R. (2006). How to design a more sustainable and fairer built environment: transport and communications. Intelligent Transport Systems, IEE Proceedings, 153(4), 276-291. doi:10.1049/ip-its:20060009

Barry, B. (1965). Political argument. London: Routledge \& Kegan Paul.

Basta, C. (2015). From justice in planning toward planning for justice: A capability approach. Planning Theory, 1473095215571399. doi: $10.1177 / 1473095215571399$

Benenson, I., Martens, K., Rofé, Y., \& Kwartler, A. (2011). Public transport versus private car GIS-based estimation of accessibility applied to the Tel Aviv 
metropolitan area. Annals of Regional Science, 47(3), 499-515. doi:10.1007/s00168-010-0392-6

Beyazit, E. (2011). Evaluating Social Justice in Transport: Lessons to be Learned from the Capability Approach. Transport Reviews, 31(1), 117-134. doi:10.1080/01441647.2010.504900

Bills, T., Sall, E., \& Walker, J. (2012). Activity-Based Travel Models and Transportation Equity Analysis. Transportation Research Record: Journal of the Transportation Research Board, 2320, 18-27. doi:10.3141/2320-03

Booth, C., \& Richardson, T. (2001). Placing the public in integrated transport planning. Transport Policy, 8(2), 141-149. doi:10.1016/S0967-070X(01)00004-X

Cass, N., Shove, E., \& Urry, J. (2005). Social exclusion, mobility and access. The Sociological Review, 53(3), 539-555. doi:10.1111/j.1467-954X.2005.00565.x

Chakraborty, J. (2006). Evaluating the environmental justice impacts of transportation improvement projects in the US. Transportation Research Part D: Transport and Environment, 11(5), 315-323. doi:10.1016/j.trd.2006.06.003

Church, A., Frost, M., \& Sullivan, K. (2000). Transport and social exclusion in London. Transport Policy, 7(3), 195-205. doi:10.1016/S0967-070X(00)00024-X

Currie, G. (2010). Quantifying spatial gaps in public transport supply based on social needs. Journal of Transport Geography, 18(1), 31-41. doi:10.1016/j.jtrangeo.2008.12.002

Davoudi, S., \& Brooks, E. (2014). When does unequal become unfair? Judging claims of environmental injustice. Environment and Planning A, 46(11), 2686-2702. doi:10.1068/a130346p

Delbosc, A., \& Currie, G. (2011). Using Lorenz curves to assess public transport equity. Journal of Transport Geography, 19(6), 1252-1259. doi:10.1016/j.jtrangeo.2011.02.008

Delmelle, E. C., \& Casas, I. (2012). Evaluating the spatial equity of bus rapid transitbased accessibility patterns in a developing country: The case of Cali, Colombia. Transport Policy, 20, 36-46. doi:10.1016/j.tranpol.2011.12.001

Dworkin, R. (1981). What is equality? Part 1: Equality of welfare. Philosophy \& Public Affairs, 10(3), 185-246.

Estache, A., \& Gómez $\square$ Lobo, A. (2005). Limits to competition in urban bus services in developing countries. Transport Reviews, 25(2), 139-158. doi:10.1080/0144164042000289654

Fainstein, S. S. (2010). The just city. Ithaca: Cornell University Press.

Farrington, J., \& Farrington, C. (2005). Rural accessibility, social inclusion and social justice: towards conceptualisation. Journal of Transport Geography, 13(1), 112. doi:10.1016/j.jtrangeo.2004.10.002

Farrington, J. H. (2007). The new narrative of accessibility: its potential contribution to discourses in (transport) geography. Journal of Transport Geography, 15(5), 319-330. doi:10.1016/j.jtrangeo.2006.11.007

Feitelson, E. (2002). Introducing environmental equity dimensions into the sustainable transport discourse: issues and pitfalls. Transportation Research Part D: 
Transport and Environment, 7(2), 99-118. doi:10.1016/S1361-9209(01)00013$\mathrm{X}$

Fincher, R., \& Iveson, K. (2012). Justice and Injustice in the City. Geographical Research, 50(3), 231-241. doi:10.1111/j.1745-5871.2011.00742.x

Flamm, M., \& Kaufmann, V. (2006). Operationalising the Concept of Motility: A Qualitative Study. Mobilities, 1(2), 167-189. doi:10.1080/17450100600726563

Forkenbrock, D. J., \& Schweitzer, L. A. (1999). Environmental justice in transportation planning. Journal of the American Planning Association, 65(1), 96-111.

Foth, N., Manaugh, K., \& El-Geneidy, A. M. (2013). Towards equitable transit: Examining transit accessibility and social need in Toronto, Canada, 1996-2006. Journal of Transport Geography, 29, 1-10. doi:10.1016/j.jtrangeo.2012.12.008

Fraser, N. (1995). Recognition or Redistribution? A Critical Reading of Iris Young's Justice and the Politics of Difference*. Journal of Political Philosophy, 3(2), 166-180. doi:10.1111/j.1467-9760.1995.tb00033.x

Geurs, K. T., Boon, W., \& Van Wee, B. (2009). Social Impacts of Transport: Literature Review and the State of the Practice of Transport Appraisal in the Netherlands and the United Kingdom. Transport Reviews, 29(1), 69-90. doi:10.1080/01441640802130490

Glaister, S., Starkie, D., \& Thompson, D. (1990). The Assessment: Economic Policy for Transport. Oxford Review of Economic Policy, 6(2), 1-21. doi:10.1093/oxrep/6.2.1

Hananel, R., \& Berechman, J. (2016). Justice and transportation decision-making: The capabilities approach. Transport Policy, 49, 78-85. doi:10.1016/j.tranpol.2016.04.005

Hausman, D. M., \& McPherson, M. S. (2006). Economic analysis, moral philosophy, and public policy (2nd ed. .). New York; Cambridge: Cambridge University Press.

Hay, A. (1993). Equity and welfare in the geography of public transport provision. Journal of Transport Geography, 1(2), 95-101. doi:10.1016/09666923(93)90003-I

Hay, A., \& Trinder, E. (1991). Concepts of equity, fairness, and justice expressed by local transport policymakers. Environment and Planning C: Government and Policy, 9(4), 453 - 465. doi:10.1068/c090453

Hodgson, F. C., \& Turner, J. (2003). Participation not consumption: the need for new participatory practices to address transport and social exclusion. Transport Policy, 10(4), 265-272. doi:10.1016/j.tranpol.2003.08.001

Jaramillo, C., Lizárraga, C., \& Grindlay, A. L. (2012). Spatial disparity in transport social needs and public transport provision in Santiago de Cali (Colombia). Journal of Transport Geography, 24, 340-357. doi:10.1016/j.jtrangeo.2012.04.014

Kain, J. F. (1968). Housing Segregation, Negro Employment, and Metropolitan Decentralization. The Quarterly Journal of Economics, 82(2), 175-197. doi: $10.2307 / 1885893$ 
Karlström, A., \& Franklin, J. P. (2009). Behavioral adjustments and equity effects of congestion pricing: Analysis of morning commutes during the Stockholm Trial. Transportation Research Part A: Policy and Practice, 43(3), 283-296. doi:10.1016/j.tra.2008.09.008

Karner, A., \& Niemeier, D. (2013). Civil rights guidance and equity analysis methods for regional transportation plans: a critical review of literature and practice. Journal of Transport Geography, 33, 126-134. doi:10.1016/j.jtrangeo.2013.09.017

Kaufmann, V., Bergman, M. M., \& Joye, D. (2004). Motility: mobility as capital. International Journal of Urban and Regional Research, 28(4), 745-756. doi:10.1111/j.0309-1317.2004.00549.x

Kawabata, M., \& Shen, Q. (2007). Commuting inequality between cars and public transit: The case of the San Francisco Bay Area, 1990-2000. Urban Studies, 44(9), 1759-1780. doi:10.1080/00420980701426616

Kellerman, A. (2012). Potential Mobilities. Mobilities, 7(1), 171-183. doi:10.1080/17450101.2012.631817

Kenyon, S., Lyons, G., \& Rafferty, J. (2002). Transport and social exclusion: investigating the possibility of promoting inclusion through virtual mobility. Journal of Transport Geography, 10(3), 207-219. doi:10.1016/S09666923(02)00012-1

Khisty, C. (1996). Operationalizing Concepts of Equity for Public Project Investments. Transportation Research Record, 1559(1), 94-99. doi:10.3141/1559-12

Klein, D. B., Moore, A. T., \& Reja, B. (2003). Curb Rights Eliciting Competition and Entrepreneurship in Urban Transit (SSRN Scholarly Paper No. ID 473441). Rochester, NY: Social Science Research Network. Retrieved from http://papers.ssrn.com/abstract $=473441$

Kronlid, D. (2008). Mobility as Capability. In T. P. Uteng \& T. Cresswell (Eds.), Gendered Mobilities (pp. 15-34). Aldershot: Ashgate.

Kwan, M.-P. (1998). Space-Time and Integral Measures of Individual Accessibility: A Comparative Analysis Using a Point-based Framework. Geographical Analysis, 30(3), 191-216. doi:10.1111/j.1538-4632.1998.tb00396.x

Kymlicka, W. (2002). Contemporary political philosophy: an introduction (2nd ed.). Oxford: Oxford University Press.

Levinson, D. (2010). Equity Effects of Road Pricing: A Review. Transport Reviews, 30(1), 33-57. doi:10.1080/01441640903189304

Litman, T. (2002). Evaluating Transportation Equity. World Transport Policy \& Practice, 8(2), 50-65.

Lucas, K. (2012). Transport and social exclusion: Where are we now? Transport Policy, 20, 105-113. doi:10.1016/j.tranpol.2012.01.013

Lucas, K., Wee, B. van, \& Maat, K. (2015). A method to evaluate equitable accessibility: combining ethical theories and accessibility-based approaches. Transportation, 1-18. doi:10.1007/s11116-015-9585-2

Martens, K. (2011). Substance precedes methodology: on cost-benefit analysis and equity. Transportation, 38(6), 959-974. doi:10.1007/s11116-011-9372-7 
Martens, K. (2012). Justice in transport as justice in accessibility: applying Walzer's "Spheres of Justice" to the transport sector. Transportation, 39(6), 1035-1053. doi:10.1007/s11116-012-9388-7

Martens, K. (2016). Transport justice: designing fair transportation systems [electronic resource]. London: Routledge.

Martens, K., \& Golub. (2012). A justice-theoretic exploration of accessibility measures. In K. T. Geurs, K. J. Krizek, A. Reggiani, \& Network on European Communications and Transport Activity Research (Eds.), Accessibility analysis and transport planning: challenges for Europe and North America (pp. 195210). Cheltenham: Edward Elgar.

Martens, K., Golub, A., \& Robinson, G. (2012). A justice-theoretic approach to the distribution of transportation benefits: Implications for transportation planning practice in the United States. Transportation Research Part A: Policy and Practice, 46(4), 684-695. doi:10.1016/j.tra.2012.01.004

Meijers, E., Hoekstra, J., Leijten, M., ... Spaans, M. (2012). Connecting the periphery: distributive effects of new infrastructure. Journal of Transport Geography, 22, 187-198. doi:10.1016/j.jtrangeo.2012.01.005

Miller, D. (1999). Principles of social justice. Cambridge, Mass; London: Harvard University Press.

Miller, H. J. (2006). Social exclusion in space and time. In K. Axhausen (Ed.), Moving through Nets: The Social and Physical Aspects of Travel. London: Elsevier.

Mullen, C. (2012). Mobility (transport). In R. F. Chadwick, Encyclopedia of applied ethics (2nd ed., Vol. 3, pp. 137-144). London: Academic Press.

Mullen, C., Tight, M., Whiteing, A., \& Jopson, A. (2014). Knowing their place on the roads: What would equality mean for walking and cycling? Transportation Research Part A: Policy and Practice, 61, 238-248. doi:10.1016/j.tra.2014.01.009

Murray, A. T., \& Davis, R. (2001). Equity in regional service provision. Journal of Regional Science, 41(4), 577-600.

Neutens, T., Schwanen, T., Witlox, F., \& Maeyer, P. D. (2010). Equity of urban service delivery: a comparison of different accessibility measures. Environment and Planning A, 42(7), 1613 - 1635. doi:10.1068/a4230

Nordbakke, S., \& Schwanen, T. (2015). Transport, unmet activity needs and wellbeing in later life: exploring the links. Transportation, 1-23. doi:10.1007/s11116-0149558-X

Nozick, R. (2003). Anarchy, state, and Utopia. [electronic resource]. Oxford: Blackwell.

Nussbaum, M. C. (2011). Creating capabilities: the human development approach. Cambridge, Mass.: Belknap Press of Harvard University Press.

Ong, P. M. (2002). Car ownership and welfare-to-work. Journal of Policy Analysis and Management, 21(2), 239-252. doi:10.1002/pam.10025

Páez, A., Mercado, R. G., Farber, S., ... Roorda, M. (2010). Relative Accessibility Deprivation Indicators for Urban Settings: Definitions and Application to Food 
Deserts in Montreal. Urban Studies, 47(7), 1415-1438. doi: $10.1177 / 0042098009353626$

Preston, J., \& Rajé, F. (2007). Accessibility, mobility and transport-related social exclusion. Journal of Transport Geography, 15(3), 151-160. doi:10.1016/j.jtrangeo.2006.05.002

Pucher, J. (1981). Equity in Transit Finance: Distribution of Transit Subsidy Benefits and Costs Among Income Classes. Journal of the American Planning Association, 47(4), 387-407. doi:10.1080/01944368108976521

Pucher, J. (1982). Discrimination in Mass Transit. Journal of the American Planning Association, 48(3), 315-326. doi:10.1080/01944368208976181

Rawls, J. (1999). A theory of justice (revised edition.). Cambridge, Mass.: Belknap Press of Harvard University Press.

Rawls, J. (2001). Justice as fairness : a restatement. Cambridge, Mass; London: Harvard University Press.

Rietveld, P., Rouwendal, J., \& van der Vlist, A. (2007). Equity Issues in the Evaluation of Transport Policies and Transport Infrastructure Projects. In M. S. van Geenhuizen, A. Reggiani, \& P. Rietveld (Eds.), Policy analysis of transport networks. Aldershot: Ashgate.

Robeyns, I. (2003). Sen's Capability Approach and Gender Inequality: Selecting Relevant Capabilities. Feminist Economics, 9(2-3), 61-92. doi:10.1080/1354570022000078024

Robeyns, I. (2005). The Capability Approach: a theoretical survey. Journal of Human Development, 6(1), 93-117. doi:10.1080/146498805200034266

Ryan, J., Wretstrand, A., \& Schmidt, S. M. (2015). Exploring public transport as an element of older persons' mobility: A Capability Approach perspective. Journal of Transport Geography, 48, 105-114. doi:10.1016/j.jtrangeo.2015.08.016

Sanchez, T. W., Stolz, R., \& Ma, J. S. (2003). Moving to equity: addressing inequitable effects of transportation policies on minorities. Cambridge, MA: Civil Rights Project at Harvard University and Center for Community Change. Retrieved from goo.gl/n18BZY

Sandel, M. J. (2009). Justice: what's the right thing to do? (1st ed. .). New York: Farrar, Straus and Giroux.

Santos, G., Behrendt, H., Maconi, L., ... Teytelboym, A. (2010). Part I: Externalities and economic policies in road transport. Research in Transportation Economics, 28(1), 2-45. doi:10.1016/j.retrec.2009.11.002

Santos, G., \& Rojey, L. (2004). Distributional impacts of road pricing: The truth behind the myth. Transportation, 31(1), 21-42. doi:10.1023/B:PORT.0000007234.98158.6b

Schweitzer, L., \& Valenzuela, A. (2004). Environmental Injustice and Transportation: The Claims and the Evidence. Journal of Planning Literature, 18(4), 383-398. doi: $10.1177 / 0885412204262958$

Sen, A. (1979). Equality of what? The Tanner Lectures on Human Values, 1, 353-369.

Sen, A. (1999). Development as freedom. New York: Anchor books. 
Sen, A. (2005). Human Rights and Capabilities. Journal of Human Development, 6(2), 151-166. doi:10.1080/14649880500120491

Sen, A. (2009). The idea of justice. Cambridge, Mass: Belknap Press of Harvard Univ. Press.

Smith, N., Hirsch, D., \& Davis, A. (2012). Accessibility and capability: the minimum transport needs and costs of rural households. Journal of Transport Geography, 21, 93-101. doi:10.1016/j.jtrangeo.2012.01.004

Soja, E. W. (2010). Seeking spatial justice. Minneapolis: University of Minnesota Press. Thomopoulos, N., Grant-Muller, S., \& Tight, M. R. (2009). Incorporating equity considerations in transport infrastructure evaluation: Current practice and a proposed methodology. Evaluation and Program Planning, 32(4), 351-359. doi:10.1016/j.evalprogplan.2009.06.013

Trinder, E., Hay, A., Dignan, J., ... Skorupski, J. (1991). Concepts of equity, fairness, and justice in British transport legislation, 1960 - 88. Environment and Planning C: Government and Policy, 9(1), 31 - 50. doi:10.1068/c090031

Tyler, N. (2006). Capabilities and Radicalism: Engineering Accessibility in the $21 \mathrm{st}$ century. Transportation Planning and Technology, 29(5), 331-358. doi:10.1080/03081060600917629

Van Wee, B. (2012). How suitable is CBA for the ex-ante evaluation of transport projects and policies? A discussion from the perspective of ethics. Transport Policy, 19(1), 1-7. doi:10.1016/j.tranpol.2011.07.001

Van Wee, B., \& Geurs, K. (2011). Discussing equity and social exclusion in accessibility evaluations. European Journal of Transport and Infrastructure Research, 11(4). Retrieved from http://www.ejtir.tbm.tudelft.nl/issues/2011_04/abstracts/2011_04_01.asp

Van Wee, B., \& Roeser, S. (2013). Ethical Theories and the Cost-Benefit AnalysisBased Ex Ante Evaluation of Transport Policies and Plans. Transport Reviews, 33(6), 743-760. doi:10.1080/01441647.2013.854281

Vasconcellos, E. A. de. (2005). Transport metabolism, social diversity and equity: The case of São Paulo, Brazil. Journal of Transport Geography, 13(4), 329-339. doi:10.1016/j.jtrangeo.2004.10.007

Viegas, J. M. (2001). Making urban road pricing acceptable and effective: searching for quality and equity in urban mobility. Transport Policy, 8(4), 289-294. doi:10.1016/S0967-070X(01)00024-5

Wachs, M., \& Kumagai, K. (1973). Physical accessibility as a social indicator. SocioEconomic Planning Sciences, 7(5), 437-456. doi:10.1016/0038-0121(73)900414

Welch, T. F. (2013). Equity in transport: The distribution of transit access and connectivity among affordable housing units. Transport Policy, 30, 283-293. doi:10.1016/j.tranpol.2013.09.020

Winston, C. (2000). Government Failure in Urban Transportation. Fiscal Studies, 21(4), 403-425. doi:10.1111/j.1475-5890.2000.tb00030.x

Young, I. M. (1990). Justice and the Politics of Difference. Princeton University Press. 